\title{
Expansion and Phenotypic Changes of Mouse Bone Marrow Mesenchymal Cells Cultured with FGF-2 and Facial Nerve- Conditioned Medium
}

\author{
Expansión y Cambios Fenotípicos de Células Mesenquimales de Médula Ósea \\ de Ratón Cultivadas con FGF-2 y Medio Condicionado por el Nervio Facial
}

Eudes Euler de Souza Lucena ${ }^{1}$; Hécio Henrique Araújo de Morais ${ }^{1}$; Dayane Pessoa de Araújo ${ }^{1}$; José Rodolfo Lopes de Paiva Cavalcanti $^{1}$; Eduardo Pereira de Azevedo²; Dinalva Brito de Queiroz ${ }^{2}$; Marco Antônio Botelho²; Amália Cinthia Meneses do Rêgo $^{2}$; Irami Araújo Filho ${ }^{1}$; Carlos Augusto Galvão Barboza ${ }^{3}$ : Expedito Silva do Nascimento Júnior; ; Miriam Stela Maris de Oliveira Costa ${ }^{3}$; Jeferson de Sousa Cavalcante ${ }^{4} \&$ Fausto Pierdoná Guzen $^{1,2}$

LUCENA, E. E. S.; DE MORAIS, H. H. A.; ARAÚJO, D. P.; CAVALCANTI, J. R. L. P.; AZEVEDO, E. P.; QUEIROZ, D. B.; BOTELHO, M.A.; RÊGO, A. C. M.; FILHO, I.A.; BARBOZA, C. A. G.; JÚNIOR, E. S. N.; COSTA, M. S. M. O.; CAVALCANTE, J. S. \& GUZEN, F. P. Expansion and phenotypic changes of mouse bone marrow mesenchymal cells cultured with FGF-2 and facial nerve-conditioned medium. Int. J. Morphol., 36(3):1049-1056, 2018.

SUMMARY: Mesenchymal cells (MCs) exhibit great regenerative potential due to their intrinsic properties and ability to restore tissue function, either directly through transdifferentiation or indirectly through paracrine effects. This study aimed to evaluate morphometric and phenotypic changes in MCs grown with facial nerve-conditioned medium in the presence or absence of fibroblast growth factor 2 (FGF-2). For quantitative phenotypic analysis, the expression of GFAP, OX-42, MAP-2, $\beta$-tubulin III, NeuN, and NF-200 was analyzed by immunocytochemistry. Cells cultured with facial nerve-conditioned medium in the presence of FGF-2 expressed GFAP, OX-42, MAP-2, $\beta$-tubulin III, NeuN, and NF-200. On average, the area and perimeter of GFAP-positive cells were higher in the group cultured with facial nerve-conditioned medium compared to the group cultured with conditioned medium and FGF- 2 ( $\mathrm{p}=0.0001$ ). This study demonstrated the plasticity of MCs for neuronal and glial lineages and opens up new research perspectives in cell therapy and trans.differentiation.

KEY WORDS: Mesenchymal stem cells; Facial nerve injury; Fibroblast growth factor 2; Conditioned medium; Plasticity; Trans-differentiation.

\section{INTRODUCTION}

The plasticity or ability of cells to transdifferentiate has raised great interest in regenerative medicine and this ability is directly related to the potential use of these cells in tissue engineering. In this respect, mesenchymal cells (MCs) have shown promising potential. Bone marrow contains two distinct populations of stem cells (SCs): hematopoietic SCs and stromal progenitors, which can give rise to different cell types including bone, cartilage, tendons, muscles, and adipose tissue (Caplan, 1994). Stem cells have been used in combination with artificial scaffolds and acellular grafts, which contributed to the improvement of electrophysiological, morphometric and/or behavioral recovery in animal models (Vitry et al., 2003). Although their potential to produce functional myelin in vivo has been questioned, it has been shown that Schwann cells derived from bone marrow SCs are able to produce myelin in vitro (Keilhoff et al., 2006).

Numerous mechanisms have been proposed to explain the regulation of cell division and self-renewal. The expansion mechanism can be symmetric or asymmetric. In asymmetric division, each SC undergoes division in which

${ }^{1}$ Laboratory of Experimental Neurology, Department of Biomedical Sciences, Health Science Center, State University of Rio Grande do Norte, MossoróRN, Brazil.

${ }^{2}$ Postgraduate Program in Biotechnology, Health School, Laureate International Universities -Potiguar University, Natal-RN, Brazil.

${ }^{3}$ Laboratory of Neuroanatomy, Department of Morphology, Bioscience Center, Federal University of Rio Grande do Norte, University Campus, NatalRN, Brazil.

${ }^{4}$ Laboratory of Neurochemical Studies, Department of Physiology, Bioscience Center, Federal University of Rio Grande do Norte, University Campus, Natal-RN, Brazil. 
LUCENA, E. E. S.; DE MORAIS, H. H. A.; ARAÚJO, D. P.; CAVALCANTI, J. R. L. P. AZEVEDO, E. P.; QUEIROZ, D. B.; BOTELHO, M. A ; RÊGO, A. C. M.; FILHO, I. A.; BARBOZA, C. A. G.; JÚNIOR, E. S. N.; COSTA, M. S. M. O.; CAVALCANTE, J. S. \& GUZEN, F. P. Expansion and phenotypic changes of mouse bone marrow mesenchymal cells cultured with FGF-2 and facial nerve-conditioned medium. Int. J. Morphol., 36(3):1049-1056, 2018.

one cell remains at rest (original stage of rest) and the other cell, called the parent, acquires the ability to differentiate. In symmetric division, two identical daughter cells or two different cells are formed from each SC. The environment influences the biochemical and morphological properties of SCs, which adapt to the surroundings and select specific lines according to the stimuli received by their niche (Fuchs $\&$ Segre, 2000). In general, cell division and differentiation are influenced by extrinsic and intrinsic factors. Neurotrophic factors can temporarily influence these processes.

Neurotrophic factors are polypeptides that play a role in the regeneration of the peripheral nervous system. These proteins essentially comprise a set of molecules and their receptors responsible for maintaining the growth and survival of sensory and motor axons and neurons after tissue damage. Trophic factors, also known as growth factors, have been used and tested in vitro and in vivo for the regeneration of peripheral nerves. These proteins act directly on the proliferation and differentiation of different cell types, promoting tissue repair and functional recovery (Boyd \& Gordon, 2003).

Several neurotrophic factors are released and act together after peripheral nerve injury to stimulate neural regeneration, including nerve growth factor (NGF), a brainderived neurotrophic factor (Boyd \& Gordon), neurotrophin 3 (NT-3) (Markus et al., 2002), insulin growth factors (IGFI and IGF-II) (Perlson et al., 2004), and fibroblast growth factor 2 (FGF-2) (Terenghi, 1999). FGF-2 is a pleiotropic growth factor that is involved in several cellular pathways during embryogenesis and in adult life (Eswarakumar et al., 2005; Thisse \& Thisse, 2005). Although described as an inhibitor of cellular senescence, FGF-2 is also a potent mitogen for different cell types (Coutu et al., 2011).

Although the implementation of SC-based strategies in clinical settings is promising, the understanding of the differentiation and proliferative capacity of SCs in vitro, the optimization of cell inoculation and the careful investigation of the outcome of transplanted cells are needed to ensure safety and maximum effectiveness of these therapies. The control of plasticity is a complex event that requires the transformation of cells in an undifferentiated state to a given state of development. Cell determination is viewed as a static event that is induced by intrinsic factors and aided by extrinsic factors.

According to Muñoz-Elias et al. (2004), MCs exhibit typical changes in neuronal morphology after 3 hours of exposure to neural induction medium. Caddick et al. (2006) and Mahay et al. (2008) demonstrated that the biochemical and functional characteristics of MCs differentiated in vitro are similar to those of Schwann cells. Caddick et al. observed that most of the cells exhibited stretching and bipolarity after 14 days of differentiation. Similarly, Lin et al. (2008) demonstrated that MCs exhibit neuronal morphology after 3 days when suitably induced.

In recent years, extensive research has been done on the therapeutic efficacy of mesenchymal SCs (Matsushita, 2016). Owing to their unique abilities of self-renewal and multilineage differentiation, including neuronal, glial, and mesodermal cells (Bae et al., 2011; Zeng et al., 2011; De Luca et al., 2013), numerous preclinical studies have reported the protective role of mesenchymal SCs in regenerative medicine (D'Souza et al., 2015).

The manipulation of environmental signals can induce cell differentiation in certain lineages and can increase our understanding of the mechanisms of neural and glial development. Therefore, the aim of this study was to evaluate morphometric and phenotypic changes in MCs grown with facial nerve-conditioned medium in the presence or absence of FGF-2.

\section{MATERIAL AND METHOD}

Male Wistar rats weighing approximately $250 \mathrm{~g}$ were used. The study was approved by the Ethics Committee on Animal Experiments of Rio Grande do Norte State University (Protocol number 007/2012) and was conducted in accordance with the ethical principles adopted by the Brazilian Society for Laboratory Animal Science. The animals were separated from their mothers after weaning to avoid any suffering or stress and were kept in separate cages in an animal house under appropriate housing conditions, with free access to food and water, until they reached the appropriate weight and age.

Mesenchymal bone marrow SCs were collected from six 3-month-old Wistar rats. The animals were killed with an overdose of the anesthetic (ketamine and xylazine, Agener Uniãoß) and the femur and tibia were removed under aseptic conditions. Under laminar flow, 60-mm culture plates were prepared with cell culture medium. The culture medium used was KnockOut Dulbecco's Modified Eagle's Medium (DMEM) supplemented with $10 \%$ fetal bovine serum, 10 $\mathrm{U} / \mathrm{ml}$ penicillin $\mathrm{G}, 10 \mu \mathrm{g} / \mathrm{ml}$ streptomycin, and $25 \mu \mathrm{g} / \mathrm{ml}$ amphotericin B $\left(\mathrm{Gibco}^{\circledR}\right)$.

In animals from which MCs were extracted after euthanasia, the facial regions were shaved. The buccal and mandibular branches of the facial nerve were identified and 
LUCENA, E. E. S.; DE MORAIS, H. H. A.; ARAÚJO, D. P.; CAVALCANTI, J. R. L. P.; AZEVEDO, E. P.; QUEIROZ, D. B.; BOTELHO, M. A.; RÊGO, A. C. M.; FILHO, I. A.; BARBOZA, C. A. G.; JÚNIOR, E. S. N.; COSTA, M. S. M. O.; CAVALCANTE, J. S. \& GUZEN, F. P. Expansion and phenotypic changes of mouse bone marrow mesenchymal cells cultured with FGF-2 and facial nerve-conditioned medium. Int. J. Morphol., 36(3):1049-1056, 2018.

isolated through a preauricular approach in both antimeres. The dissected nerves were cut into 1-mm long explants. Under laminar flow, the nerve fragments were transferred to 60-mm plates containing DMEM medium supplemented with $10 \%$ fetal bovine serum and $0.1 \%$ gentamicin. On average, 18 explants of the facial nerve were plated on each P60 plate. Viability of the facial nerve explants was evaluated by a slight migration of fibroblastoid morphology of cells around the explants (Fig. 1).

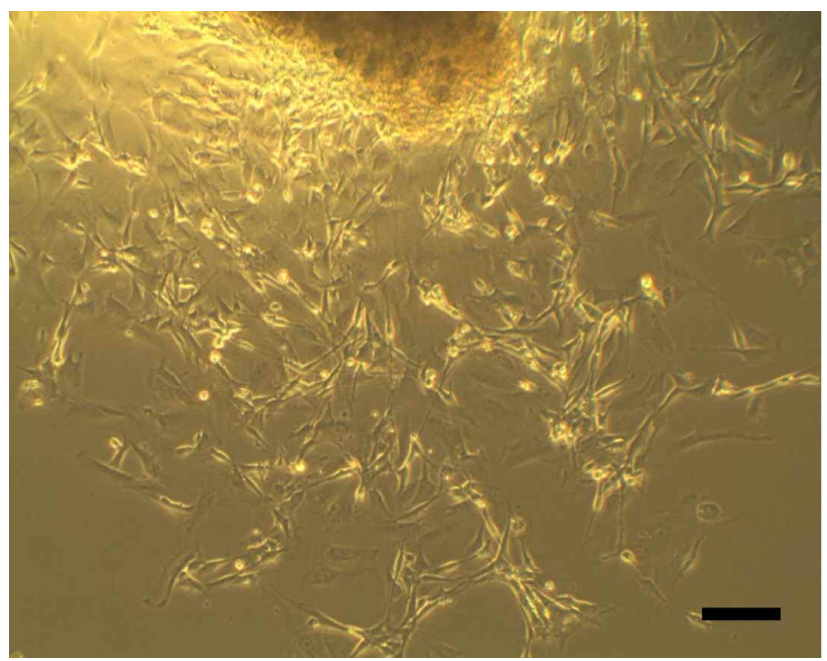

Fig. 1. Viability of facial nerve explants and cellular migration (10x). Scale bar: $100 \mu \mathrm{m}$.

Aliquots containing $1 \times 10^{6}$ cells were plated onto 48 P60 plates, which were divided into two groups: group 1, bone marrow MCs + facial nerve-conditioned medium; group 2, bone marrow MCs + facial nerve-conditioned medium + FGF-2. In groups 1 and 2, one ml of medium conditioned with facial nerve that had been transferred at least once to another plate was added. In group 2, $1 \mathrm{ml}$ FGF-2 $\left(\right.$ Sigma $\left.^{\circledR}\right)$ was added at a concentration of 1:10 (Guzen et al., 2012).

The cells were observed under a CKX41 inverted phase-contrast microscope (Olympus ${ }^{\circledR}$ ) coupled to a Moticam 3.0 (Motic $^{\circledR}$ ) digital camera at three culture intervals (24, 48, and 72 hours) to monitor cell adhesion and proliferation. After 72 hours of observation, the plates were used for the immunocytochemistry procedures.

On the third day (72 hours), the medium was removed and cells adhered to the plates were washed twice for 5 minutes in $0.1 \mathrm{M}$ phosphate-buffered saline (PBS), $\mathrm{pH}$ 7.4 , fixed in paraformaldehyde (4\%) for 30 minutes, and washed three times in PBS (5 minutes each). The cells were then treated with $0.5 \%$ Triton $\left(\operatorname{Sigma}^{\circledR}\right)$ for 10 minutes and washed in PBS. Next, nonspecific sites were blocked for 30 minutes in a solution of $0.1 \mathrm{M}$ PBS containing 0.2 $\%$ Triton and $1 \%$ bovine serum albumin. The cells were then incubated for 2 hours at room temperature with the following primary antibodies: anti-mouse GFAP (Sigma, 1:400), anti-mouse OX-42 (Millipore, 1:500), anti-mouse MAP-2 (Abcam, 1:2000), anti-rabbit $\beta$-tubulin III (Millipore, 1:500), anti-mouse NeuN (Millipore, 1:500), and anti-mouse NF-200 (Abcam, 1:1200). The cells were washed in 0.1 M PBS ( $\mathrm{pH} 7.4$ ) for 5 minutes, incubated for 1 hour with anti-mouse and anti-rabbit secondary antibodies produced in donkey (Jackson, USA) and conjugated to AlexaFluor 488, AlexaFluor 594, FITC or TRITC fluorophore, and kept under refrigeration protected from light. After incubation with the secondary antibodies, the cells were washed in PBS for 5 minutes and immediately examined under a fluorescence microscope (Eclipse E200, Nikon ${ }^{\circledR}$ ) and later under another fluorescence microscope (Eclipse Ni, Nikon ${ }^{\circledR}$ ).

The presence of fluorescent staining in MCs was recorded, with careful examination of immunoreactivity in the subcellular, cytoplasmic, and nuclear compartments. Two previously calibrated independent investigators $($ kappa $=0.94)$ measured the perimeter $(\mu \mathrm{m})$ and area $\left(\mathrm{mm}^{2}\right)$ of each cell in nonoverlapping random fields, using cell images from three different plates at 10x magnification. The Motic Images Plus 2.0 software $\left(\right.$ Motic $^{\circledR}$ ) was used for morphological/morphometric analysis, the ImageJ software for cell count, and the Adobe Photoshop CS6.0 software (Adobe) to adjust minimum brightness and contrast of the photomicrographs.

The database was constructed using the SPSS 22.0 software (Statistical Package for the Social Sciences), followed by verification of data consistency. Descriptive statistics were used for analysis of the data (area and perimeter of immunostained cells). The results were compared by the Mann-Whitney $U$ test and t-test for independent groups and differences were considered significant when $\mathrm{p}<0.05$.

\section{RESULTS}

After 72 hours of observation, immunocytochemistry was performed in the two experimental groups and different fluorescent microscope filters were used to verify the staining in MCs. Cells of group 1 (conditioned medium) expressed GFAP and OX-42 (Fig. 2 A and B, respectively). Cells of group 2 (conditioned medium + FGF-2) expressed GFAP, OX-42, MAP-2, b-tubulin III, NeuN, and NF-200 (Figs. 3 A, B, C, D, E and F, respectively). 
LUCENA, E. E. S.; DE MORAIS, H. H. A.; ARAÚJO, D. P.; CAVALCANTI, J. R. L. P.; AZEVEDO, E. P.; QUEIROZ, D. B.; BOTELHO, M. A.; RÊGO, A. C. M.; FILHO, I. A.; BARBOZA, C. A. G.; JÚNIOR, E. S. N.; COSTA, M. S. M. O.; CAVALCANTE, J. S. \& GUZEN, F. P. Expansion and phenotypic changes of mouse bone marrow mesenchymal cells cultured with FGF-2 and facial nerve-conditioned medium. Int. J. Morphol., 36(3):1049-1056, 2018.
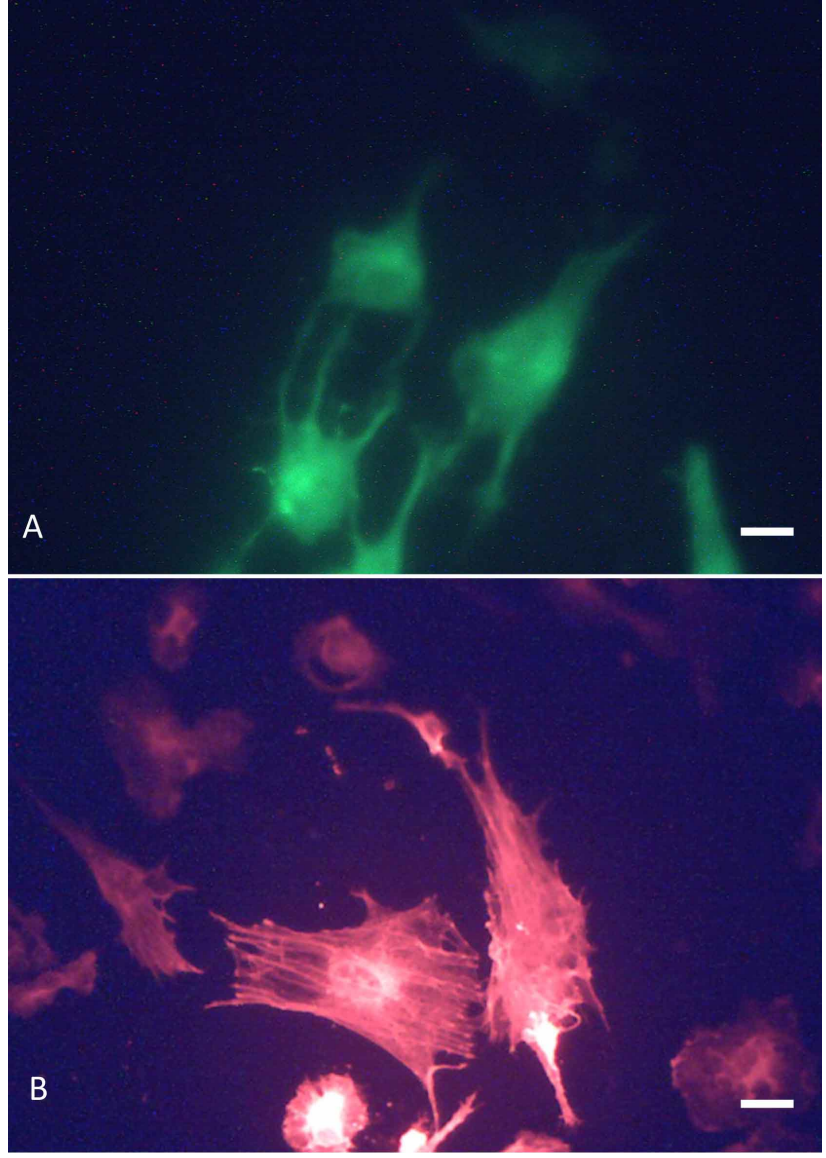

Fig. 2. Immunofluorescent staining in mesenchymal cells of group 1 treated with the GFAP/Alexa 488 (A) and OX-42/TRITC (B) antibodies (20x) on day 3. Scale bar: $100 \mu \mathrm{m}$.

In group 1, migration of GFAP and OX-42 immunoreactivity from the cytoplasm to the nuclear compartment of the cells was observed, along with a higher intensity of staining. In addition, lower and narrower staining was found in the cytoplasmic compartment. In group 2, several cells with the characteristic bipolar shape were identified, as well as cells with typical mesenchymal morphology. Brighter uniform staining for b-tubulin III could be observed throughout the cytoplasm, as well as staining for OX-42 and MAP-2 in the nuclear compartment.

The average area and perimeter of GFAP-positive cells were greater in group 1 than in group $2(\mathrm{p}=0.0001)$ (Fig. 4).

\section{DISCUSSION}

Mesenchymal cells derived from bone marrow are considered a promising source of SCs because of their accessibility, plasticity potential and differentiation capacity. The techniques used for the purification, expansion and osteogenic, chondrogenic and adipogenic differentiation of MCs can address the challenges of tissue engineering (Liu et al., 2013). Since they are multipotent, MCs meet the requirements of an ideal cell transplant, including rapid in vitro expansion and low immunogenicity. Furthermore, MCs can differentiate into Schwann cells (Keilhoff et al.).

For appropriate function, cells must organize themselves in space and interact mechanically with the surrounding environment. They must have a correct conformation, be physically robust, and be appropriately structured internally. Many cells must also be able to change their shape and to migrate to other locations. In addition, every cell must be able to reorganize its internal components in response to growth processes and division and adapt to changes in the environment (Alberts et al., 2010).

The mechanisms that govern the in vivo differentiation and migration of MCs to the sites of injury are still unclear; however, neurotrophic factors, cytokines and local SCs are likely to play a role. Understanding the environment in which these cells are cultured permits to improve cell expansion methods and to develop different plasticity protocols. Adult SCs are influenced by the environment that surrounds them, i.e., by epigenetic factors. Once these factors are removed, SCs are free to take a different path (Rieske et al., 2009).

An important finding of the present study were the morphological changes that occurred in the cells as the days progressed. Cells grown with conditioned medium (groups 1 and 2) exhibited rapid morphological changes, resembling neurons and glial cells. Fibroblastoid and fusiform (group 2) features were also identified.

The biological functions of mesenchymal SCs (also referred to as mesenchymal stromal cells) range from tissue repair/regeneration to immunomodulatory activity (Salem \& Thiemermann, 2010; Le Blanc \& Mougiakakos, 2012; Ma et al., 2014). Furthermore, different culture conditions or additional treatment can regulate or enhance the biological functions of mesenchymal SCs. Their multifunctional properties have made mesenchymal SCs the subject of numerous animal studies and clinical trials investigating their use to treat a wide range of diseases.

The most important factor determining cell survival in a recipient tissue is the microenvironment. Initially, this aspect is related to the expression of cell surface adhesion markers, which interact with extracellular matrix components. Added to the paracrine effects of growth factors 
LUCENA, E. E. S.; DE MORAIS, H. H. A.; ARAÚJO, D. P.; CAVALCANTI, J. R. L. P.; AZEVEDO, E. P.; QUEIROZ, D. B.; BOTELHO, M. A.; RÊGO, A. C. M.; FILHO, I. A.; BARBOZA, C. A. G.; JÚNIOR, E. S. N.; COSTA, M. S. M. O.; CAVALCANTE, J. S. \& GUZEN, F. P. Expansion and phenotypic changes of mouse bone marrow mesenchymal cells cultured with FGF-2 and facial nerve-conditioned medium. Int. J. Morphol., 36(3):1049-1056, 2018.
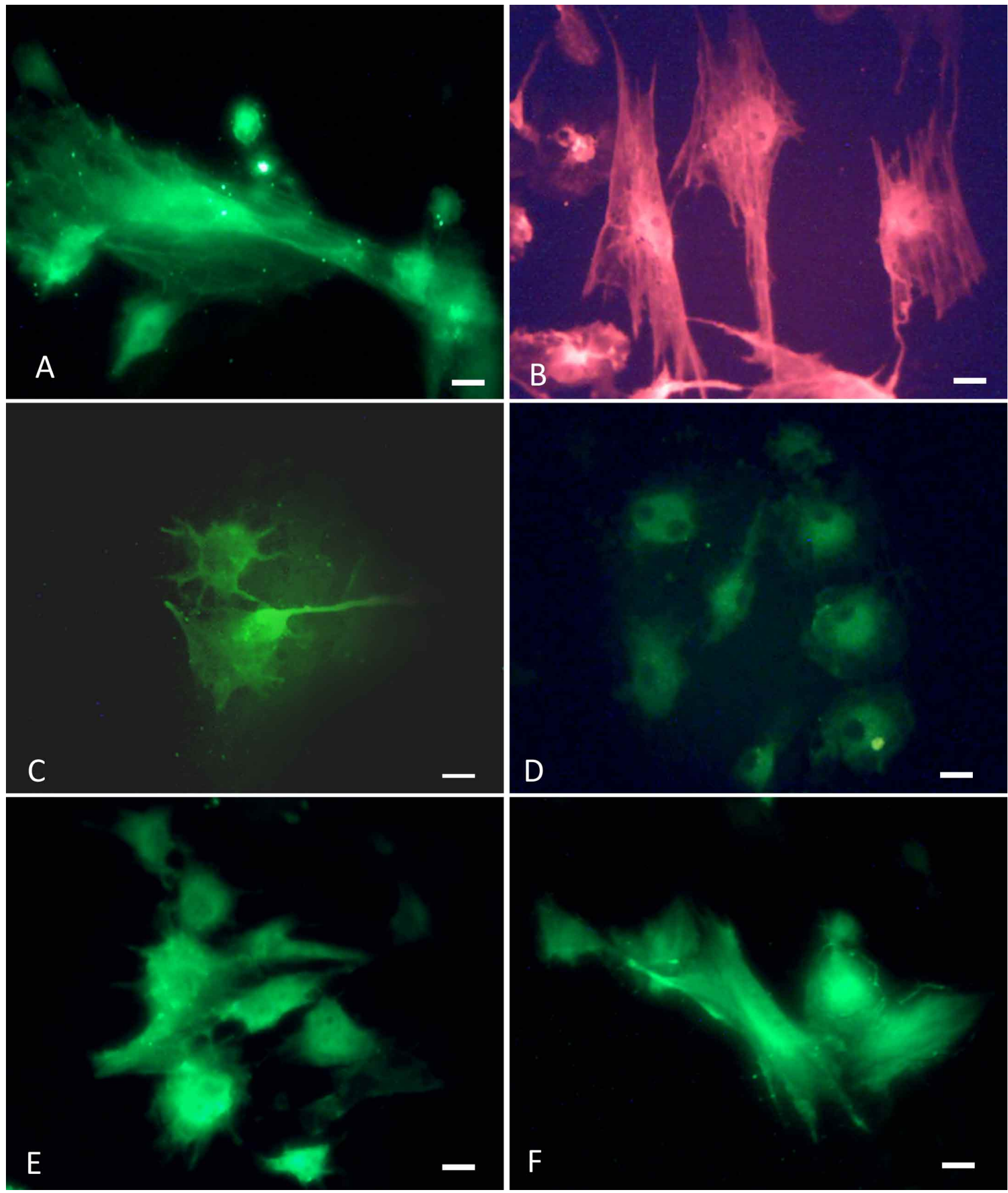

Fig. 3. Immunofluorescent staining in mesenchymal cells of group 2 treated with the GFAP/Alexa 488 (A), OX-42/TRITC (B), MAP-2/FITC (C), b-tubulin III/FITC (D), NeuN/Alexa 488 (E), and NF-200/Alexa 488 (F) antibodies (20x) on day 3 (72 hours). Scale bar: $100 \mu \mathrm{m}$.

secreted by surrounding cells, the microenvironment provides conditions for survival, migration, invasion, and tissue differentiation (Caddick et al.). Neuronal differentiation can currently be achieved in four ways: use 
LUCENA, E. E. S.; DE MORAIS, H. H. A.; ARAÚJO, D. P.; CAVALCANTI, J. R. L. P.; AZEVEDO, E. P.; QUEIROZ, D. B.; BOTELHO, M. A.; RÊGO, A. C. M.; FILHO, I. A.; BARBOZA, C. A. G.; JÚNIOR, E. S. N.; COSTA, M. S. M. O.; CAVALCANTE, J. S. \& GUZEN, F. P. Expansion and phenotypic changes of mouse bone marrow mesenchymal cells cultured with FGF-2 and facial nerve-conditioned medium. Int. J. Morphol., 36(3):1049-1056, 2018.

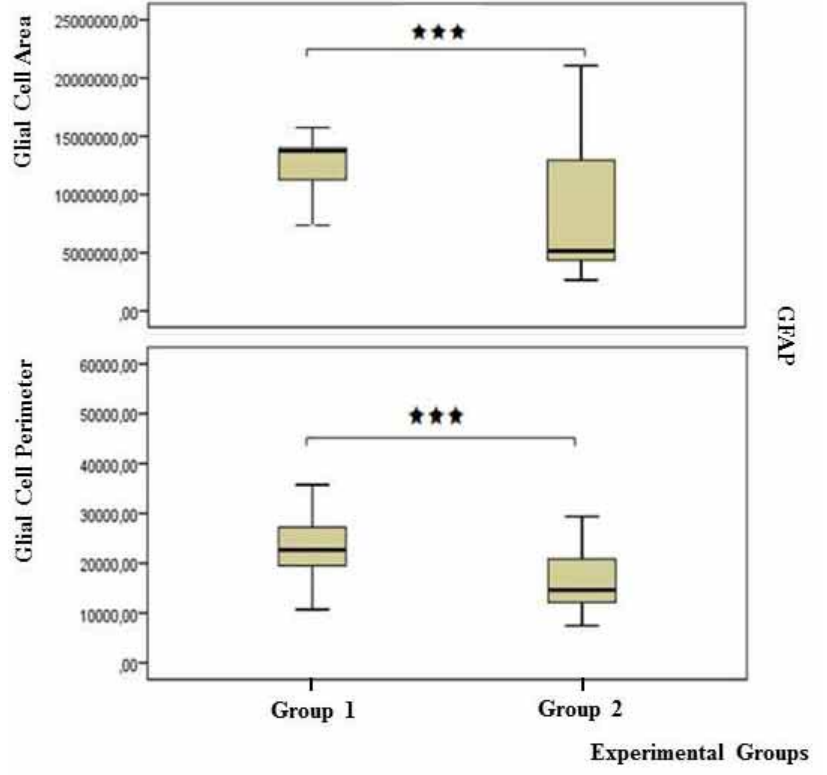

Fig. 4. Area and perimeter of GFAP-positive mesenchymal cells in groups 1 and 2 observed on day 3 (72 hours) (***p=0.0001, MannWhitney U test).

of neurotrophic factors or cytokines, exposure to chemical inducers, or a combination of these nerve cell co-cultures (Yang et al., 2014).

In our study, the medium created from nerve fragments simulated a nerve injury situation. Thus, the explants became reactive and naturally secreted factors that would provide a favorable environment for nerve regeneration after trauma. As the properties of neurotrophic factors are quite discussed, the use of FGF-2 could enhance the phenotypic effects of cells and increase their proliferative activity.

Within this context, the exquisite specificity of antibodies makes them valuable reagents for the detection, quantification and purification of antigens and enables the use of protocols for the investigation of cell differentiation or plasticity. Thus, this study used immunocytochemistry as the technique of choice to identify the plasticity of MCs in different culture media. The antibodies used were neuronal lineage markers (MAP-2, b-tubulin III, NeuN and NF-200) and glial lineage markers (GFAP and OX-42). Our experiments showed that cells grown with facial nerveconditioned medium in the presence of FGF-2 expressed MAP-2, b-tubulin III, NeuN, and NF-200. It was hypothesized that FGF-2 enhances the phenotypic expression of group 2 cells over a short period of time after induction (3 days). Such behavior becomes important, as it can induce a "transdifferentiation" in vitro when inoculating these cells in order to induce regeneration of the nervous system. In fact, the histological organization of the facial nerve may contribute to the rapid release of neurotrophic factors into the medium. Thus, the microenvironment simulated by medium conditioned with facial nerve explants could explain the speed of neuronal and glial differentiation. Alternative non-anatomical explanations such as a difference in the degenerative and/or regenerative capacity of the nerves after trauma are also possible (Barghash et al., 2013).

Furthermore, Zainal Ariffin et al. (2013) examined the direct differentiation of dental pulp-derived neurons in the absence of an inducing chemical. To confirm the differentiation of dental pulp cells into a neuronal phenotype and to demonstrate that this stage was not an artifact, the authors performed three analyses: observation of morphological changes, expression of MAP-2, and expression of neuronal markers. Two days after induction, the majority of cells resembled neurons. However, some fibroblastoid cells were still observed. After 5 days, the cells differentiated into neurons when cultured in a medium free of growth factors.

Huang et al. (2007) evaluated the plasticity of fat cells. For induction of cell differentiation, the cells were washed in PBS and DMEM containing $10 \mathrm{mM}$ forskolin, $200 \mathrm{mM} 0.5 \%$ ethanol, $5 \mathrm{mM} \mathrm{KCl}, 2 \mathrm{mM}$ valproic acid, 1 $\mathrm{mM}$ hydrocortisone, and $5 \mathrm{mg} / \mathrm{mL}$ insulin. After neuronal induction, adipocytic SCs exhibited changes in cell morphology, including cytoplasmic retraction and the formation of axons and dendritic projections. In addition, SCs expressed adipocytic MAP-2 and b-tubulin III along the cell body and neuritic processes similar to those observed in neurons.

Krampera et al. (2007) treated bone marrow MCs with different molecules and growth factors and observed rapid morphological changes typical of neuronal cells, as well as the expression of neural markers such as nestin, neurofilament, NeuN, and MAP-2. For neural induction, the cells were grown in basal medium containing DMEM and fetal bovine serum supplemented with $5 \mathrm{ng} / \mathrm{mL}$ fibroblast growth factor for 24 hours. After this pre-induction, the cells were washed in PBS and supplemented with $\mathrm{KCl}$, valproic acid, and phospholine.

The control of size is essential for the development and differentiation of organs and tissues. The size of a cell depends on the cell type and its stage in the cell cycle (Kharitonova \& Vasiliev, 2008). In culture, changes occur in the number, size, and area of cells during growth (Vasiliev et al., 2004). The shape of the cell is controlled by internal cytoskeletal structures and adhesion molecules fixed to the 
LUCENA, E. E. S.; DE MORAIS, H. H. A.; ARAÚJO, D. P.; CAVALCANTI, J. R. L. P.; AZEVEDO, E. P.; QUEIROZ, D. B.; BOTELHO, M. A.; RÊGO, A. C. M.; FILHO, I. A.; BARBOZA, C. A. G.; JÚNIOR, E. S. N.; COSTA, M. S. M. O.; CAVALCANTE, J. S. \& GUZEN, F. P. Expansion and phenotypic changes of mouse bone marrow mesenchymal cells cultured with FGF-2 and facial nerve-conditioned medium. Int. J. Morphol., 36(3):1049-1056, 2018.

cell surface (Moizhess \& Vasiliev, 2001; Rovensky et al., 2001). The control of cell shape involves the organization within the plasma membrane of a contact surface with the extracellular environment (surrounding cells, extracellular matrix, culture medium) (Levayer \& Lecuit, 2008). Integrins are versatile signaling receptors that permit the exchange between the external and internal environment. Many processes such as cell morphology, motility, proliferation, differentiation, and cell death are possible because of this pathway (Docheva et al., 2007).

Mesenchymal cells have been proposed as promising candidates for tissue regeneration based on their easy accessibility, rapid expansion, low immunogenicity, and multipotency. When exposed to classical chemical cocktails, MCs adopt specific phenotypes, express cell-specific markers, and exhibit functional characteristics. However, the expression of markers and functional characteristics are transient after the inducing agent is withdrawn. Within this context, it is necessary to optimize the culture conditions for differentiation in order to produce cells with stable features that can be used in clinical therapeutic procedures.

\section{CONCLUSION}

The area and perimeter of GFAP-positive cells were greater in group 1 (conditioned medium) than in group 2 (conditioned medium + FGF-2). These findings suggest that FGF-2 promotes the expression of neuronal proteins, which could contribute to peripheral nerve regeneration.

\section{ACKNOWLEDGMENTS}

This work was supported by the National Council for Technological and Scientific Development (CNPq, Brazil).

LUCENA, E. E. S.; DE MORAIS, H. H. A.; ARAÚJO, D. P.; CAVALCANTI, J. R. L. P.; AZEVEDO, E. P.; QUEIROZ, D. B.; BOTELHO, M. A.; RÊGO, A. C. M.; FILHO, I. A.; BARBOZA, C. A. G.; JÚNIOR, E. S. N.; COSTA, M. S. M. O.; CAVALCANTE, J. S. \& GUZEN, F. P. Expansión y cambios fenotípicos de células mesenquimales de médula ósea de ratón cultivadas con FGF-2 y medio condicionado por el nervio facial. Int. J. Morphol., 36(3):1049-1056, 2018.

RESUMEN: Las células mesenquimales (CM) exhiben un gran potencial regenerativo debido a sus propiedades intrínsecas y la capacidad de restaurar la función del tejido, ya sea directa- mente, a través de la transdiferenciación, o indirectamente, a través de efectos parácrinos. Este estudio tuvo como objetivo evaluar los cambios morfométricos y fenotípicos en CM cultivadas con medio condicionado por nervio facial en presencia o ausencia de factor de crecimiento de fibroblastos 2 (FGF-2). Para el análisis fenotípico cuantitativo, se analizó la expresión de GFAP, OX-42, MAP-2, $\beta$-tubulina III, NeuN y NF-200 mediante inmunocitoquímica. Las células cultivadas con medio condicionado por el nervio facial en presencia de FGF-2 expresaban GFAP, OX-42, MAP-2, $\beta$-tubulina III, NeuN y NF-200. En promedio, el área y el perímetro de las células positivas para GFAP fueron mayores en el grupo cultivado con medio condicionado por el nervio facial en comparación con el grupo cultivado con medio acondicionado y FGF-2 ( $\mathrm{p}=0,0001)$. Este estudio demostró la plasticidad de CM para linajes neuronales y gliales y abre nuevas perspectivas de investigación en terapia celular y transdiferenciación.

PALABRAS CLAVE: Células madre mesenquimales; Lesión del nervio facial; Factor de crecimiento de fibroblastos 2; Medio condicionado; Plasticidad; Trans-diferenciación.

\section{REFERENCES}

Alberts, B.; Bray, O.; Hopkin, K.; Johnson, A.; Lewis, J. \& Raff, M. Biologia Molecular da Célula. Porto Alegre, Artmed, 2010.

Bae, K. S.; Park, J. B.; Kim, H. S.; Kim, D. S.; Park, D. J. \& Kang, S. J. Neuron-like differentiation of bone marrow-derived mesenchymal stem cells. Yonsei Med. J., 52(3):401-12, 2011.

Barghash, Z.; Larsen, J. O.; Al-Bishri, A. \& Kahnberg, K. E. Degeneration and regeneration of motor and sensory nerves: a stereological study of crush lesions in rat facial and mental nerves. Int. J. Oral Maxillofac. Surg., 42(12):1566-74, 2013.

Boyd, J. G. \& Gordon, T. Neurotrophic factors and their receptors in axonal regeneration and functional recovery after peripheral nerve injury. Mol. Neurobiol., 27(3):277-324, 2003.

Caddick, J., Kingham, P. J.; Gardiner, N. J.; Wiberg, M. \& Terenghi, G. Phenotypic and functional characteristics of mesenchymal stem cells differentiated along a Schwann cell lineage. Glia, 54(8):840-9, 2006.

Caplan, A. I. The mesengenic process. Clin. Plast. Surg., 21(3):429-35, 1994.

Coutu, D. L.; François, M. \& Galipeau, J. Inhibition of cellular senescence by developmentally regulated FGF receptors in mesenchymal stem cells. Blood, 117(25):6801-12, 2011.

D’Souza, N.; Rossignoli, F.; Golinelli, G.; Grisendi, G.; Spano, C.; Candini, O.; Osturus, S.; Catani, F.; Paolucci, P.; Horwitz, E. M. \& Dominici, M. Mesenchymal stem/stromal cells as a delivery platform in cell and gene therapies. BMC Med., 13:186, 2015.

De Luca, A.; Verardi, R.; Neva, A.; Benzoni, P.; Crescini, E.; Xia, E.; Almini, C.; Calza, S. \& Dell'Era, P. Comparative analysis of mesenchymal stromal cells biological properties. ISRN Stem Cells, 2013:674671, 2013.

Docheva, D.; Popov, C.; Mutschler, W. \& Schieker, M. Human mesenchymal stem cells in contact with their environment: surface characteristics and the integrin system. J. Cell Mol. Med., 11(1):21-38, 2007.

Eswarakumar, V. P.; Lax, I. \& Schlessinger, J. Cellular signaling by fibroblast growth factor receptors. Cytokine Growth Factor Rev., 16(2):139-49, 2005.

Fuchs, E. \& Segre, J. A. Stem cells: a new lease on life. Cell, 100(1):14355, 2000. 
LUCENA, E. E. S.; DE MORAIS, H. H. A.; ARAÚJO, D. P.; CAVALCANTI, J. R. L. P; AZEVEDO, E. P.; QUEIROZ, D. B.; BOTELHO, M. A.; RÊGO, A. C. M.; FILHO, I. A.;

BARBOZA, C. A. G.; JÚNIOR, E. S. N.; COSTA, M. S. M. O.; CAVALCANTE, J. S. \& GUZEN, F. P. Expansion and phenotypic changes of mouse bone marrow mesenchymal cells cultured with FGF-2 and facial nerve-conditioned medium. Int. J. Morphol., 36(3):1049-1056, 2018.

Guzen, F. P.; Soares, J. G.; de Freitas, L. M.; Cavalcanti, J. R.; Oliveira, F. G.; Araújo, J. F.; Cavalcante, J. de S.; Cavalcante, J. C.; do Nascimento, E. S.Jr. \& de Oliveira Costa, M. S. Sciatic nerve grafting and inoculation of FGF-2 promotes improvement of motor behavior and fiber regrowth in rats with spinal cord transection. Restor. Neurol. Neurosci., 30(3):265$75,2012$.

Huang, T.; He, D.; Kleiner, G. \& Kuluz, J. Neuron-like differentiation of adipose-derived stem cells from infant piglets in vitro. J. Spinal Cord. Med., 30 Suppl. 1:S35-40, 2007.

Keilhoff, G.; Stang, F.; Goihl, A.; Wolf, G. \& Fansa, H. Transdifferentiated mesenchymal stem cells as alternative therapy in supporting nerve regeneration and myelination. Cell. Mol. Neurobiol., 26(7-8):1235-52, 2006.

Kharitonova, M. A. \& Vasiliev, J. M. Controlling cell length. Semin. Cell Dev. Biol., 19(6):480-4, 2008.

Krampera, M.; Marconi, S.; Pasini, A.; Galiè, M.; Rigotti, G.; Mosna, F.; Tinelli, M.; Lovato, L.; Anghileri, E.; Andreini, A.; Pizzolo, G.; Sbarbati, A. \& Bonetti, B. Induction of neural-like differentiation in human mesenchymal stem cells derived from bone marrow, fat, spleen and thymus. Bone, 40(2):382-90, 2007.

Le Blanc, K. \& Mougiakakos, D. Multipotent mesenchymal stromal cells and the innate immune system. Nat. Rev. Immunol., 12(5):383-96, 2012.

Levayer, R. \& Lecuit, T. Breaking down EMT. Nat. Cell Biol., 10(7):7579, 2008.

Lin, W., Chen, X.; Wang, X.; Liu, J. \& Gu, X. Adult rat bone marrow stromal cells differentiate into Schwann cell-like cells in vitro. In Vitro Cell. Dev. Biol. Anim., 44(1-2):31-40, 2008.

Liu, Y.; Liu, L.; Ma, X.; Yin, Y.; Tang, B. \& Li, Z. Characteristics and neural-like differentiation of mesenchymal stem cells derived from foetal porcine bone marrow. Biosci. Rep., 33(2):351-60, 2013.

Ma, S.; Xie, N.; Li, W.; Yuan, B.; Shi, Y. \& Wang, Y. Immunobiology of mesenchymal stem cells. Cell Death Differ., 21(2):216-25, 2014.

Mahay, D.; Terenghi, G. \& Shawcross, S. G. Growth factors in mesenchymal stem cells following glial-cell differentiation. Biotechnol. Appl. Biochem., 51(Pt. 4):167-76, 2008.

Markus, A.; Patel, T. D. \& Snider, W. D. Neurotrophic factors and axonal growth. Curr. Opin. Neurobiol., 12(5):523-31, 2002.

Matsushita, K. Mesenchymal stem cells and metabolic syndrome: Current understanding and potential clinical implications. Stem Cells Int., 2016:2892840, 2016

Moizhess, T. G. \& Vasiliev, J. M. Substrate-induced polarisation of cultured epitheliocytes and fibroblasts: non-reactivity of Ras-transformed cells. Cell Biol. Int., 25(9):931-4, 2001.

Muñoz-Elias, G.; Marcus, A. J.; Coyne, T. M.; Woodbury, D. \& Black, I. B. Adult bone marrow stromal cells in the embryonic brain: Engraftment, migration, differentiation, and long-term survival. $J$. Neurosci., 24(19):4585-95, 2004.

Perlson, E.; Hanz, S.; Medzihradszky, K. F.; Burlingame, A. L. \& Fainzilber, M. From snails to sciatic nerve: Retrograde injury signaling from axon to soma in lesioned neurons. J. Neurobiol., 58(2):287-94, 2004.

Rieske, P.; Augelli, B. J.; Stawski, R.; Gaughan, J.; Azizi, S. A. \& Krynska, B. A population of human brain cells expressing phenotypic markers of more than one lineage can be induced in vitro to differentiate into mesenchymal cells. Exp. Cell Res., 315(3):462-73, 2009.

Rovensky, Y. A.; Domnina, L. W.; Ivanova, O. Y. \& Vasiliev, J. M. Responses of epithelial and fibroblast-like cells to discontinuous configuration of the culture substrate. Membr. Cell Biol., 14(5):617-27, 2001.

Salem, H. K. \& Thiemermann, C. Mesenchymal stromal cells: current understanding and clinical status. Stem Cells, 28(3):585-96, 2010.

Terenghi, G. Peripheral nerve regeneration and neurotrophic factors. J. Anat., 194(Pt. 1):1-14, 1999.

Thisse, B. \& Thisse, C. Functions and regulations of fibroblast growth factor signaling during embryonic development. Dev. Biol., 287(2):390402, 2005.

Vasiliev, J. M. Cytoskeletal mechanisms responsible for invasive migration of neoplastic cells. Int. J. Dev. Biol., 48(5-6):425-39, 2004.
Vitry, S.; Bertrand, J. Y.; Cumano, A. \& Dubois-Dalcq, M. Primordial hematopoietic stem cells generate microglia but not myelin-forming cells in a neural environment. J. Neurosci., 23(33):10724-31, 2003.

Yang, J. D.; Cheng-Huang; Wang, J. C.; Feng, X. M.; Li, Y. N. \& Xiao, H. $\mathrm{X}$. The isolation and cultivation of bone marrow stem cells and evaluation of differences for neural-like cells differentiation under the induction with neurotrophic factors. Cytotechnology, 66(6):1007-19, 2014

Zainal Ariffin, S. H.; Kermani, S.; Zainol Abidin, I. Z.; Megat Abdul Wahab, R.; Yamamoto, Z.; Senafi, S.; Zainal Ariffin, Z. \& Abdul Razak, M. Differentiation of dental pulp stem cells into neuron-like cells in serumfree medium. Stem Cells Int., 2013:250740, 2013.

Zeng, R.; Wang, L. W.; Hu, Z. B.; Guo, W. T.; Wei, J. S.; Lin, H.; Sun, X.; Chen, L. X. \& Yang, L. J. Differentiation of human bone marrow mesenchymal stem cells into neuron-like cells in vitro. Spine (Phila Pa 1976), 36(13):997-1005, 2011.

Corresponding author:

Fausto Pierdoná Guzen, PhD

Full Professor

Department of Biomedic Sciences

Health Sciences Faculty

State University of Rio Grande do Norte

Zip code: 59607-360, Mossoró

Rio Grande do Norte

BRAZIL

Email: faustoguzen@uern.br

Received:19-12-2017

Accepted: 23-03-2018 